\title{
Troponin T level and mortality risk after noncardiac surgery: practical implications of the VISION study
}

\author{
Wojciech Szczeklik ${ }^{1}$, P.J. Devereaux ${ }^{2}$ \\ 1 2nd Department of Medicine, Jagiellonian University Medical College, Kraków, Poland \\ 2 Departments of Clinical Epidemiology and Biostatistics and Medicine, McMaster University, Hamilton, Ontario, Canada
}

\section{KEY WORDS}

mortality, noncardiac surgery, risk prediction, troponin $\mathrm{T}$
Correspondence to:

Dr. P.J. Devereaux, Population Health Research Institute, David Braley Cardiac, Vascular, and Stroke Research Institute, Perioperative Medicine and Surgical Research Unit, c/o Hamilton General Hospital, 237 Barton Street East, Hamilton, ON, Canada, L8L 2X2, phone: + 1-905-527-4322 fax: +1-905-297-3778, e-mail:philipj@mcmaster.ca Received: August 30, 2012. Accepted: August 31, 2012 Conflict of interest: W.S. and P.J.D. are investigators of the VISION study.

Pol Arch Med Wewn. 2012; 122 (10): 499-503

Copyright by Medycyna Praktyczna, Kraków 2012

\begin{abstract}
This review article presents the current state of knowledge about major perioperative cardiovascular complications in noncardiac surgery patients and the role of the currently available stratification models and biomarkers in risk prediction. The authors discuss a recent paper presented by the VISION Investigators in the June edition of the Journal of the American Medical Association and its practical implications in day-to-day perioperative practice. According to this study, the authors conclude that troponin $(\mathrm{Tn})$ measurement up to 3 days after noncardiac surgery substantially improves perioperative risk estimation, and peak Tn values (even the levels previously considered as normal) strongly predict 30-day mortality. One in 25 patients with a peak fourth generation troponin T (TnT) measurement of $0.02 \mu \mathrm{g} / \mathrm{l}$, 1 in 11 patients with a peak TnT measurement of 0.03 to $0.29 \mu \mathrm{g} / \mathrm{l}$, and 1 in 6 patients with a peak TnT measurement of $0.30 \mu \mathrm{g} / \mathrm{l}$ or higher will die within 30 days of surgery. Postoperative monitoring of $\mathrm{TnT}$ measurements substantially improves risk stratification after noncardiac surgery and may help identify patients requiring further therapeutic interventions.
\end{abstract}

Over the last few decades, the field of noncardiac surgery has undergone substantial changes. The introduction of new surgical techniques, combined with improved anesthesia, has improved surgical care; however, the age and comorbidities of patients undergoing noncardiac surgery has increased. Worldwide, more than 200 million patients undergo major noncardiac surgery annually, and this number continues to grow. ${ }^{1}$ Despite the benefits of surgery, major postsurgical complications occur, of which cardiovascular (i.e., vascular death, nonfatal myocardial infarction [MI], nonfatal cardiac arrest, and nonfatal stroke) are the most common serious complications. ${ }^{2}$ Further, more than 1 million patients die within 30 days following noncardiac surgery annually.

Of the major perioperative cardiovascular complications, MI is the most common. The pathogenesis of perioperative MI (PMI) is not fully understood; however, two main mechanisms have emerged as the most probable. The first mechanism is that PMI shares the same pathophysiology as the majority of nonoperative acute coronary syndromes (i.e., plaque rupture, fissuring, or erosion with consequent superimposed arterial thrombosis). This hypothesis is supported, among others, by the fact that surgery activates the inflammatory process and the coagulation cascade and acts on stress-related pathways. Moreover, cardiac catheterization data comparing patients who have suffered a PMI, a nonoperative acute coronary syndrome, or who have undergone elective cardiac catheterization suggest that many patients suffering a PMI have catheterization findings similar to nonoperative acute coronary syndrome patients. ${ }^{3}$

The second proposed mechanism of PMI is supply-demand mismatch. ${ }^{4-6}$ It is potentially provoked by many factors that commonly take place during surgery, such as fluid shifts, hypotension, catecholamine release, pain, anemia, tachycardia, or hypoxia. Additionally, as the population ages, many patients that undergo a surgical procedure end up having accompanying coronary artery disease, which in turn places them in a higher-risk 
group, as most patients with PMI have some degree of underlying coronary stenosis. ${ }^{7,8}$

The diagnosis of a PMI has challenges because it typically occurs in the first 48 hours after surgery ${ }^{9,10}$ when most patients are receiving analgesic medications that can mask cardiac ischemic symptoms, and some patients remain sedated and on mechanical ventilation, which limits communication. ${ }^{2,10-12}$ Only $35 \%$ of patients suffering a PMI will experience cardiac ischemic symptoms, ${ }^{10}$ a number which differs substantially from the emergency room setting. Changes in electrocardiogram (ECG) patterns are transient and often missed because patients, when they are having the event, experience symptoms too rarely to trigger health care providers to obtain an ECG. ${ }^{5,10}$ Regardless of the presence of symptoms, PMI occurrence is associated with an increase of 30 -day mortality up to $11.6 \% .^{10}$ Therefore, it is essential to identify patients who would require more intensive monitoring and management in order to decrease the perioperative mortality risk.

Several preoperative risk prediction indices for major vascular complications and mortality have been developed. ${ }^{13-16}$ The Revised Cardiac Risk Index (RCRI) introduced by Lee et al. ${ }^{14}$ is probably the most widely used model. It is easy to use and consists of 6 equally weighted clinical components: high-risk surgery (intraperitoneal, intrathoracic, or suprainguinal vascular surgery), history of ischemic heart disease, history of congestive heart failure, history of cerebrovascular disease (both stroke and transient ischemic attack), diabetes requiring insulin therapy, and impaired renal function with preoperative serum creatinine level above $176.8 \mu \mathrm{mol} / \mathrm{l}$. Based on their scores, patients are grouped into 3 groups at risk of developing major vascular events after surgery: low-, intermediate-, and high-risk groups (presence of at least 3 risk factors corresponds to $11 \%$ risk of complications). ${ }^{14}$ Nonetheless, the risk prediction accuracy of RCRI has been recently questioned by many authors, mostly due to underestimation of vascular complications and subsequent mortality following surgery. ${ }^{2,4,17,18}$ Moreover, methodological limitations of the original RCRI study have been raised, ${ }^{4}$ for example, that the study was conducted at a single-center, that there was a small number of events on which the index was based (only 92 adverse events), ${ }^{14}$ that there was absence of stroke as an outcome event (which is an independent serious predictor of mortality and disability after surgery),${ }^{19}$ and that patients undergoing emergency surgery were excluded even though they belong to the group with the highest risk of complications. ${ }^{15}$ Some researchers suggest also adding age into the RCRI model to improve its prediction outcomes. ${ }^{17}$

The recently published data from the large PeriOperative Ischemic Evaluation (POISE) Trial ${ }^{2,10,20}$ that included over 8000 patients in a randomized controlled trial in 190 centers in 23 countries comparing the effects of $\beta$-blockers with placebo among patients undergoing noncardiac surgery, revealed a large underestimation in the major vascular events with the use of the RCRI. According to the POISE results, the overall vascular mortality in the first 30 days after surgery was $1.6 \%$; PMI occurred in $5 \%$ of patients, stroke in $0.7 \%$, and nonfatal cardiac arrest in $0.5 \% .^{2}$ The authors concluded that physicians should expect double or triple the risk of major events as predicted by the RCRI. ${ }^{4}$

Taking into account the burden of perioperative vascular complications and the problems with diagnosing PMI, the medical community is searching for a biomarker that could predict adverse perioperative complications. Among the available biomarkers, the most specific and sensitive for MI are cardiac troponins (Tn) I and T $(\operatorname{TnT})$. They are released into the circulation as a consequence of myocardial necrosis and play a pivotal role in diagnosing MI. ${ }^{21,22}$ In the nonsurgical setting, increased levels of cardiac Tn have been shown to predict poor outcome including mortality. ${ }^{23}$ In the setting of noncardiac surgery, there is encouraging but inconclusive evidence that Tn measurements after surgery may predict short-term mortality. ${ }^{9}$ A meta-analysis performed by Levy et al. ${ }^{24}$ that included 10 studies $(n=1728)$ that evaluated noncardiac surgery patients demonstrated that an elevated cardiac Tn was an independent risk predictor of mortality up to 1 year after surgery with the odds ratio of 6.7 (95\% confidence interval [CI], 4.1-10.9; $I^{2}=0 \%$ ). The studies in this meta-analysis were, however, mostly small with few events and did not adjust for all known predictors of mortality.

The Vascular Events In Noncardiac Surgery Patients Cohort Evaluation Study (VISION; ClinicalTrials.gov identifier, NCT00512109) is the largest prospective international cohort study evaluating major complications in patients after noncardiac surgery. It is a multicenter study, led by the research team from McMaster University, that aims to recruit 40,000 patients in North and South America, Africa, Asia, Australia, and Europe. Patients are eligible for the study if they are 45 years or older, undergo noncardiac surgery (elective or urgent/emergency with either general or regional anesthesia), and require at least an overnight hospital stay. Patients have TnT measured daily during the first 3 days after surgery, and are followed up at 30 days and 1 year after surgery. At the beginning of this study, patients had the fourth generation TnT measurements after noncardiac surgery. The first 15,000 patients experienced an event rate approximately 3 times higher than what was expected at the beginning. Recognizing they had sufficient events to address their objectives related to the fourth generation TnT measurements, the Operations Committee decided to henceforth monitor the fifth generation high-sensitivity $\mathrm{TnT}$ assay. The authors then published the first major paper from VISION in The Journal of the American Medical Association 
TABLE Peak troponin T thresholds during the first 3 days after surgery that independently predict 30-day moratality

\begin{tabular}{llll}
$\begin{array}{c}\text { Peak troponin T } \\
\text { measurement }\end{array}$ & \multicolumn{2}{c}{ Patients who died within 30 days after surgery } & $\begin{array}{c}\text { Adjusted HR } \\
\text { (95\% CI) }\end{array}$ \\
$\leq 0.01 \mu \mathrm{g} / \mathrm{l}$ & $134 / 13,376$ & $\%(95 \% \mathrm{CI})$ & 1.0 \\
\hline $0.02 \mu \mathrm{g} / \mathrm{l}$ & $20 / 494$ & $1.0(0.8-1.2)$ & $2.41(1.33-3.77)$ \\
\hline $0.03-0.29 \mu \mathrm{g} / \mathrm{l}$ & $104 / 1121$ & $4.0(2.6-6.2)$ & $5.00(3.72-6.76)$ \\
\hline$\geq 0.30 \mu \mathrm{g} / \mathrm{l}$ & $24 / 142$ & $9.3(7.7-11.1)$ & $10.48(6.25-16.62)$ \\
\hline
\end{tabular}

Abbreviations: $\mathrm{Cl}$ - confidence interval, $\mathrm{HR}$ - hazard ratio, $\mathrm{n}$ - number of patients who died, $\mathrm{N}$ - total number of patients

(JAMA) evaluating the prognostic capabilities of the fourth generation TnT to predict 30-day mortality. ${ }^{25}$

The study had an equal sex distribution of men and women. Approximately $50 \%$ of the patients were 65 years of age and older and approximately 1 in 4 patients were 75 years of age and older. The most common surgeries were low-risk surgeries $(39.4 \%)$, major orthopedic (20.4\%), major general (20.3\%), and major urology/gynecology surgeries (12.5\%). Vascular surgery (3.3\%) and thoracic surgeries (2.5\%) were less common. Urgent or emergency surgery was performed in $14.2 \%$ of the patients.

The investigators evaluated predicting 30-day mortality with the Cox proportional hazard model that included 24 preoperative and surgical variables (e.g., age, coronary artery disease, type of surgery) and this model was repeated with the addition of the peak TnT measurement during the first 3 days after surgery. This approach allowed the authors to define the prognostic role of $\mathrm{TnT}$ in predicting 30-day mortality and to determine the thresholds that independently altered patients risk. ${ }^{25}$

Of 15,133 patients studied, 282 patients (95\% CI, 1.7\%-2.1\%) died during 30 days after surgery. Of this group, 26\% died after discharge from hospital, and the median time to death was 11 days (interquartile range, $4.0-15.0$ days) after discharge. The investigators were able to successfully complete the 30-day follow-up on more than $99 \%$ of the patients. The strongest predictor of death was the peak TnT measurement after surgery, with the population attributable risk analysis suggesting that $41.8 \%$ of deaths could potentially be explained by increased TnT values after surgery. A multivariable analysis demonstrated that peak TnT threshold values of $0.02 \mu \mathrm{g} / \mathrm{l}$, $0.03 \mu \mathrm{g} / \mathrm{l}$, and $0.30 \mu \mathrm{g} / \mathrm{l}$ were independently associated with 30-day mortality (TABLE).

The fourth generation TnT values of 0.02 and $0.03 \mu \mathrm{g} / \mathrm{l}$, which are not considered abnormal in daily practice, were striking predictors of 30-day mortality. The higher the peak Tn after surgery, the higher the likelihood of death, with 1 in 6 patients with TnT higher than $0.30 \mu \mathrm{g} / \mathrm{l}$ dying within 30 days of surgery. Also, the time to death is shorter with the increase of $\mathrm{TnT}$ values (i.e., 13.5 days for $\mathrm{TnT}$ values of $0.02 \mu \mathrm{g} / \mathrm{l}$ and 6.5 days for $\mathrm{TnT}$ values of $0.3 \mu \mathrm{g} / \mathrm{l}$ or higher). The postoperative peak TnT measurement substantially enhanced risk prediction beyond the preoper ative model; the net reclassification improvement with added peak TnT measurements to risk stratification based solely on preoperative variables reached $25 \%(P<0.001)$. In other words, the risk stratification model in noncardiac surgery is substantially enhanced when postoperative TnT measurements are added to the preoperative factors. It is a marker of substantial clinical utility because prognostically important elevated $\mathrm{TnT}$ values were found in $11.6 \%$ of patients 45 years of age or older undergoing noncardiac surgery, and the results were consistent throughout the international centers.

The third universal definition of MI has recently been published in a 2012 consensus statement of the European Society of Cardiology, American College of Cardiology Foundation, American Heart Association, and the World Heart Federation..$^{26}$ In this document, the international consensus group added a section for the first time on $\mathrm{MI}$ in the noncardiac surgery setting. Based on the POISE data on MI and the VISION data on Tn, this consensus document states, "routine monitoring of cardiac biomarkers in high-risk patients.. after major surgery, is therefore recommended."

At present, there are no randomized controlled trials concerning the treatment of myocardial injury as detected through an elevated Tn measurement after surgery; however, according to the available data from nonsurgical trials and observational noncardiac surgery data, it is strongly encouraged to use both acetylsalicylic acid and statin therapy in these patients. ${ }^{27,28}$ Unfortunately, it has been documented that a substantial proportion of patients suffering a myocardial injury in the perioperative period after noncardiac surgery do not receive these medications. ${ }^{10}$

Large clinical intervention randomized trials in the noncardiac perioperative field are needed to inform how to optimally manage patients suffering a myocardial injury after surgery. The VISION Investigators are about to launch a large international trial evaluating a novel new anticoagulant in this patient population. Hopefully, other investigators will get involved and will initiate other trials evaluating promising interventions to help this patient population.

In summary, the recent JAMA paper presented by the VISION Study investigators, clearly demonstrated that measuring cardiac $\mathrm{TnT}$ in the first 3 days after noncardiac surgery substantially 
improves mortality risk prediction in noncardiac surgery patients. The data suggests that 1 in 25 patients with the peak TnT measurement of $0.02 \mu \mathrm{g} / \mathrm{l}, 1$ in 11 patients with the peak TnT measurement of 0.03 to $0.29 \mu \mathrm{g} / \mathrm{l}$, and 1 in 6 patients with the peak $\mathrm{TnT}$ measurement of $0.30 \mu \mathrm{g} / \mathrm{l}$ or higher will die within 30 days of surgery. Monitoring postoperative $\mathrm{TnT}$ measurements can enhance risk stratification after noncardiac surgery, and routine perioperative Tn monitoring is now recommended by an international consensus group.

Acknowledgments Wojciech Szczeklik received a grant from the Polish Ministry of Science and Higher Education, No. NN402 083939, for the VISION substudy.

\section{REFERENCES}

1 Weiser TG, Regenbogen SE, Thompson KD, et al. An estimation of the global volume of surgery: a modelling strategy based on available data Lancet. 2008; 372: 139-144.

2 POISE Study Group, Devereaux PJ, Yang H, Yusuf S, et al. Effects of extended-release metoprolol succinate in patients undergoing non-card ac surgery (POISE trial): a randomised controlled trial. Lancet. 2008; 371 1839-1847

3 Gualandro DM, Campos CA, Calderaro D, et al. Coronary plaque rupture in patients with myocardial infarction after noncardiac surgery: frequent and dangerous. Atherosclerosis. 2012; 222: 191-195.

4 Devereaux PJ, Chan M, Eikelboom J. Major vascular complications in patients undergoing noncardiac surgery: the magnitude of the problem, risk prediction, surveillance, and prevention. In: Yusuf S, Cairns JA, Camm A et al., ed(s). Evidence-Based Cardiology. 3rd ed. London, England: BM Books; 2009: 47-62.

5 Landesberg G, Beattie WS, Mosseri M, et al. Perioperative myocardia infarction. Circulation. 2009; 119: 2936-2944.

6 Devereaux PJ, Goldman L, Cook DJ, et al. Perioperative cardiac events in patients undergoing noncardiac surgery: a review of the magnitude of the problem, the pathophysiology of the events and methods to estimate and communicate risk. CMAJ. 2005;173: 627-634.

7 Cohen MC, Aretz TH. Histological analysis of coronary artery lesions in fatal postoperative myocardial infarction. Cardiovasc Pathol. 1999; 8 : 133-139.

8 Ellis SG, Hertzer NR, Young JR, Brener S. Angiographic correlates of cardiac death and myocardial infarction complicating major nonthoracic vascular surgery. Am J Cardiol. 1996; 77: 1126-1128.

9 Le Manach Y, Perel A, Coriat $P$, et al. Early and delayed myocardial infarction after abdominal aortic surgery. Anesthesiology. 2005; 102: 885-891.

10 Devereaux PJ, Xavier D, Pogue J, et al.; POISE (PeriOperative ISchemic Evaluation) Investigators. Characteristics and short-term prognosis of perioperative myocardial infarction in patients undergoing noncardiac surgery: a cohort study. Ann Intern Med. 2011; 154: 523-528.

11 Mangano DT, Browner WS, Hollenberg M, et al. Association of perioperative myocardial ischemia with cardiac morbidity and mortality in men undergoing noncardiac surgery. The Study of Perioperative Ischemia Research Group. N Engl J Med. 1990; 323: 1781-1788.

12 Badner NH, Knill RL, Brown JE, et al. Myocardial infarction after noncardiac surgery. Anesthesiology. 1998; 88: 572-578.

13 Goldman L, Caldera DL, Nussbaum SR, et al. Multifactorial index of cardiac risk in noncardiac surgical procedures. N Engl J Med. 1977; 297: 845-850.

14 Lee TH, Marcantonio ER, Mangione CM, et al. Derivation and prospective validation of a simple index for prediction of cardiac risk of major noncardiac surgery. Circulation. 1999; 100: 1043-1049.

15 Kumar R, McKinney WP, Raj G, et al. Adverse cardiac events after surgery: assessing risk in a veteran population. J Gen Intern Med. 2001; 16 507-518

16 Detsky AS, Abrams HB, McLaughlin JR, et al. Predicting cardiac complications in patients undergoing non-cardiac surgery. J Gen Intern Med. 1986; 1: 211-219.

17 Boersma E, Kertai MD, Schouten 0, et al. Perioperative cardiovascular mortality in noncardiac surgery: validation of the Lee cardiac risk index Am J Med. 2005; 118: 1134-1141.

18 Ford MK, Beattie WS, Wijeysundera DN. Systematic review: predic tion of perioperative cardiac complications and mortality by the revised cardiac risk index. Ann Intern Med. 2010; 152: 26-35.
19 Limburg M, Wijdicks EF, Li H. Ischemic stroke after surgical procedures: clinical features, neuroimaging, and risk factors. Neurology. 1998; 50: 895-901.

20 Alonso-Coello P, Paniagua P, Mizera R, Devereaux PJ. Should physicians initiate beta-blocker therapy in patients undergoing non-cardiac surgery? In sights from the POISE trial. Pol Arch Med Wewn. 2008; 118: 616-618.

21 Thygesen K, Alpert JS, White HD; Joint ESC/ACCF/AHA/WHF Task Force for the Redefinition of Myocardial Infarction. Universal definition of myocardial infarction. J Am Coll Cardiol. 2007; 50: 2173-2195.

22 Bonaca MP, Morrow DA. Defining a role for novel biomarkers in acute coronary syndromes. Clin Chem. 2008; 54: 1424-1431.

23 Apple FS, Morrow D. Cardiac troponin in condintions other than acute coronary syndromes. In: Morrow $\mathrm{D}$, ed. Cardiovascular biomarkers: pathophysiology and disease management. Totowa, NJ: Humana Press 2006: $137-158$.

24 Levy M, Heels-Ansdell D, Hiralal R, et al. Prognostic value of troponin and creatine kinase muscle and brain isoenzyme measurement after noncardiac surgery: a systematic review and meta-analysis. Anesthesiology. 2011: 114: 796-806.

25 Vascular Events In Noncardiac Surgery Patients Cohort Evaluation Study I, Devereaux PJ, Chan MT, Alonso-Coello P, et al. Association between postoperative troponin levels and 30-day mortality among patients undergoing noncardiac surgery. JAMA. 2012; 307: 2295-2304.

26 Thygesen K, Alpert JS, Jaffe AS, et al. Third universal definition of myocardial infarction. Eur Heart J. 2012; 33: 2551-2567.

27 Antithrombotic Trialists' Collaboration. Collaborative meta-analysis of randomised trials of antiplatelet therapy for prevention of death, myocardial infarction, and stroke in high risk patients. BMJ. 2002; 324: 71-86.

28 Mills EJ, Rachlis B, Wu P, et al. Primary prevention of cardiovascular mortality and events with statin treatments: a network meta-analysis involving more than 65,000 patients. J Am Coll Cardiol. 2008; 52: 1769-1781. 


\title{
Stężenia troponin T związane z ryzykiem zgonu po zabiegu niekardiochirurgicznym - praktyczne implikacje wynikające $z$ badania VISION
}

\author{
Wojciech Szczeklik ${ }^{1}$, P.J. Devereaux ${ }^{2}$ \\ 1 II Katedra Chorób Wewnętrznych, Uniwersytet Jagielloński, Collegium Medicum, Kraków \\ 2 Departments of Clinical Epidemiology and Biostatistics and Medicine, McMaster University, Hamilton, Ontario, Kanada
}

\section{SŁOWA KLUCZOWE}

chirurgia

pozasercowa, skale

ryzyka, śmiertelność, troponina $\mathrm{T}$

\section{STRESZCZENIE}

W artykule przedstawiono aktualny stan wiedzy na temat dużych sercowo-naczyniowych powikłań okołozabiegowych w chirurgii pozasercowej oraz znaczenie dostępnych skal rokowniczych i markerów biochemicznych w ocenie ryzyka zabiegu. Autorzy omawiają również artykuł opublikowany przez grupę badaczy VISION w tegorocznym czerwcowym numerze czasopisma Journal of the American Medical Association oraz wynikające z badania praktyczne implikacje w zakresie opieki okołooperacyjnej. Analizując artykuł autorzy wnioskują, że pomiar stężeń troponin przez $\leq 3$ dni po zabiegu niekardiochirurgicznym istotnie poprawia okołooperacyjną ocenę ryzyka zabiegu, a szczytowe wartości troponin (nawet wartości wcześniej uznawane za prawidłowe) bardzo znacząco korelują z 30-dniową śmiertelnością. Analiza wpływu szczytowych wartości troponiny T czwartej generacji (TnT) na śmiertelność 30-dniową po zabiegu wykazała, że w grupie chorych z TnT 0,02 $\mu \mathrm{g} / \mathrm{l}$ umrze 1 na 25 chorych, w przedziale TnT 0,03-0,29 $\mu \mathrm{g} / \mathrm{l}-1$ na 11, a przy wartościach $\operatorname{TnT} \geq 0,30 \mu \mathrm{g} / \mathrm{l}-1$ na 6 . Pooperacyjne monitorowanie $\mathrm{TnT}$ istotnie poprawia ocenę ryzyka zabiegu w chirurgii pozasercowej, a w przyszłości może pomóc w wyselekcjonowaniu chorych wymagających dalszych interwencji terapeutycznych.
Adres do korespondencji:

Dr P.J. Devereaux, Population

Health Research Institute, David

Braley Cardiac, Vascular, and Stroke

Research Institute, Perioperative

Medicine and Surgical Research Unit,

c/o Hamilton General Hospital,

237 Barton Street East, Hamilton,

ON, Kanada, L8L 2X2,

tel.: $+1-905-527-4322$

fax: +1-905-297-3778,

e-mail:philipj@mcmaster.ca

Praca wpłynęła: 30.08.2012.

Przyjęta do druku: 31.08.2012.

Zgłoszono sprzeczność interesów:

W.S. i P.J.D. są zaangażowani w

badanie VISION.

Pol Arch Med Wewn. 2012;

122 (10): 499-503

Copyright by Medycyna Praktyczna, Kraków 2012 